\title{
ALKALOIDS OF ELAEAGNUS ANGUSTIFOLIA
}

A. G. Nikolaeva, I. V. Terent'eva, P. E. Krivenchuk, and A. P. Prokopenko

Khimiya Prirodnykh Soedineni1, Vol. 6, No. 4, p. 493,1970

UDC $547.944 / 945$

From the bark of the stems and the bark of the roots of Elaeagnus angustifolia L. , collected in the period of sap movement in the environs of the town of Zaporozh'e (Khortitsa island) we have isolated the combined alkaloids by chloroform extraction with yields of 1 and $0.02 \%$, respectively.

The separation of the combined bases from the bark into phenolic and nonphenolic fractions with subsequent chromatography on active alumina (with benzene as eluent) gave two individual substances shown by qualitative reactions to be indole derivatives.

Alkaloid I. $\mathrm{C}_{12} \mathrm{H}_{10} \mathrm{~N}_{2}$, mp $234-235^{\circ} \mathrm{C}$ (after sublimation in vacuum and recrystallization from benzene), optically inactive, $\mathrm{R}_{f} 0.43$ (TLC in a $3 \%$ methanol in chloroform system), 0.65 [paper chromatography in a butan-1-ol-acetic acid-water $(10: 1: 5)$ system]. The base gave a hydrochloride with $\mathrm{mp} 275^{\circ} \mathrm{C}$ (decomp) and a picrate with mp $250-255^{\circ} \mathrm{C}$ (decomp).

UV spectrum of alkaloid I, $\lambda_{\max }, \operatorname{m} \mu: 235,249,288$, and $336(\log \varepsilon 4.58,4.37,4.22$, and 3.68$)$. The IR spectrum contained bands at $\left(\mathrm{cm}^{-1}\right.$ ) $1630,1570,1510$, and 1450 (indole ring) and 760 (four adjacent hydrogens of an aromatic ring).

Alkaloid II. $\mathrm{C}_{12} \mathrm{H}_{14} \mathrm{~N}_{2}, \mathrm{mp} 176-177^{\circ} \mathrm{C}$ (after sublimation and recrystallization from benzene), optically inactive; its chloride and dipicrate melted at $261-263^{\circ} \mathrm{C}$ and $221.5-222.5^{\circ} \mathrm{C}$, respectively. UV spectrum, $\lambda_{\max }$ m $\mu: 224$ and $280(\log \varepsilon 4.52$ and 3.92$)$.

Base I was identified as harman from the absence of a depression of the melting point with a synthetic sample [6] and by its UV and IR spectra and chromatographic behavior (paper and thin-layer chromatography).

Base II proved to be identical with tetrahydroharman [1,3]. Harman is fairly widely distributed in the plant world $[2,4,5,7]$, but this is the first time that it has been isolated from Elaeagnus angustifolia L.

\section{REFERENCES}

1. B. A. Abdusalamov and A. S. Sadykov, Uzb. khim. zh. , no. 6, 47, 1961.

2. B. A. Abdusalamov and A. S. Sadykov, Uzb. khim. zh., no. 4, 79, 1962.

3. G. P. Men'shikov, E. A. Gurevich, and G. A. Samsonova, ZhOKh, 20, 1927, 1950.

4. I. V. Terent'eva and A. V. Borovkov, collection: Alkaloid-Bearing plants of Moldavia [in Russian], Kishinev, 41, 1960.

5. T. A. Henry, The Plant Alkaloids, London, 1939.

6. W. O. Kermack, and W. H. Perkin, R. Robinson, J. Chem. Soc., London, 119, 1617, 1921.

7. R. Neu. Arzneimittel-Forsch. , 6, 94, 1956.

15 January 1970

Zaporozh'e State Medical Institute

Institute of Chemistry, AS MoIdavian SSR

Khar'kov Scientific-Research Chemical and Pharmaceutical Institute 